\title{
The adjustment work canal on the Amudarya in the areas of the damless water intake
}

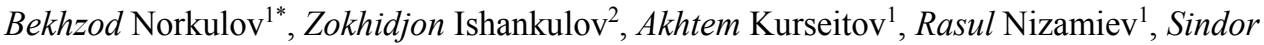 \\ Asadov $^{1}$, and Alibek Pateyev ${ }^{1}$ \\ ${ }^{1}$ Tashkent Institute of Irrigation and Agricultural Mechanization Engineers, Tashkent, Uzbekistan \\ ${ }^{2}$ Andijan Institute of Agriculture and Agricultural Technologies, Andijan, Uzbekistan
}

\begin{abstract}
The paper presents the results of field research in the area of the damless water intake of the KMC on the Amudarya River. The article developed the optimal route and boundaries of the pioneer digging location, depending on the area of the main stream of the river relative to the point of the damless intake. It also provides hydraulic calculations for improving the condition of a damless water intake and recommendations for the rational use and placement of a dredgers fleet when laying a route of a ditch and cleaning it.
\end{abstract}

Keywords: damless water intake, Amudarya, Karshi Main Canal-KMC, hydraulic calculation.

\section{Introduction}

In engineering practice, special attention is paid to the issues of scientific research of the negative impact of the canal process development on the reliability and functioning of the damless water intake, the determination of the intensity and direction of canal processes in the river canals and canals of the head structure and the development of methods for their calculation. In this regard, ensuring a guaranteed volume of water withdrawal with a minimum amount of the volume of bottom and suspended sediments at a damless water withdrawal is considered one of the important tasks [1-4].

The Amudarya is characterized by a very unstable canal and high intensity of erosion of the banks. The main reasons for the active reshaping of the Amudarya River are the presence of relatively large slopes, easy erosion of the soils that make up the bed, large fluctuations in flow rates and water levels in the intra-annual section.

The investigated section of the river. The Amudarya is located in the area of the damless water intake in the KMC (Karshi Main Canal) and is $22 \mathrm{~km}$ above the water seal of the Kerki town. The total length of the investigated section is $10-12 \mathrm{~km}$. This area has two characteristic sections: the upper one is $6 \mathrm{~km}$ upstream from the head water intake, and the lower one is located between the head water intake and the village of Kzylayak [5-10].

During water withdrawal from the Amudarya River to the KMC, difficulties arise due to the rapid siltation and sedimentation of the head section of the canal. Depending on the water content of the year, a flow with a turbidity of up to $5 \mathrm{~kg} / \mathrm{m}^{3}$ annually enters the inlet

*Corresponding author: vohidov.oybek@bk.ru 
of the canal. The annual volumes of sediments range from 8 to 12 million tons. The main stream of the Amudarya River in the area of the KMC water intake flows in a wide floodplain. As a result of field studies 2006-2019 and the materials of previous years of studying the transformations of the river main canal near the damless water intake, the optimal operation mode of the head of the water intake at low river levels during the dry season and dry years was revealed. Initially, the head of the KMC water intake was located on the eroded bank of the Amudarya River, $1.2 \mathrm{~km}$ below the stable bank of Cape Pulizindan. The rocky coast of Cape Pulizindan above the head of the water intake prevented the main stream of the river from flowing and constantly directed the flow to the left bank. As a result, in certain periods of the year, unfavorable conditions were created at the head of the KMC water intake for water withdrawal into the inlet part of the canal and did not provide the required water consumption $[11,12]$.

\section{Methods}

The analysis of the results of field studies on the Amudarya River section in the damless water intake area into the Karshi Main Canal, assessment of the state of the Amudarya River in the area of water intake and increasing the reliability of the damless water intake are the methods of research of this work.

\section{Results and discussion}

In the context of the Amudarya, with a large volume of irrigated water and intensive wandering of the river flow on a wide floodplain, the maintainig of a guaranteed damless water intake requires the implementation of the adjustment work canal to detach the pioneer dug and its systematic cleaning from entering during operation. The annual volume of such work is $30 \ldots 40 \%$ of the total volume of the head water intake area.

In the studied area, as a result of the displacement of the main stream of the river in the head water intake at a length of $1200 \mathrm{~m}$, the flow concentrated in one canal, the width of which, depending on the water discharge, varied from 250 to $500 \mathrm{~m}$. An island located between the right and middle canals at a length of $2000 \mathrm{~m}$, displaced to the left, towards the middle canal by 200-280 in the head part of the left canal formed a large sandbank. There was also an expansion to $1000 \mathrm{~m}$ and an extension to $1200 \mathrm{~m}$ of the island located between the middle and left canals [13-16]. Due to the systematic cleaning of the middle canal, the discharge in it is $80 \ldots 85 \%$ of the total discharge of the river. The canal width along the water edge was $320-350 \mathrm{~m}$. Below the water intake point, an erosion of the island located between the left and right canals was observed on the side of the right flow at a width of 80 ... $150 \mathrm{~m}$ about the length of the washout strip up to $1500 \mathrm{~m}$. They manifest themselves in different ways: both in the form of erosion, and in the form of entering. The erosion of the river bed in some places reached 0.5-1.5 m, and sediment deposits 0.2-1.4 m (Fig. 1). Planned deformations were more intense than deep ones. During the observation period, the canal width changed from 250 to $500 \mathrm{~m}$, depending on the water discharge and the curvature of the river canal. Planned deformations were more intense than deep ones. The $\mathrm{B} / \mathrm{H}$ value was $26-63$ in the area above the water intakes and 63-77 in the area below the water intake. The value of the surface water flow velocity in the area above the water intake changed from 0.78 to $1.08 \mathrm{~m} / \mathrm{s}$, below the water intake - from 0.5 to $0.75 \mathrm{~m} / \mathrm{s}$ [17-26]. 


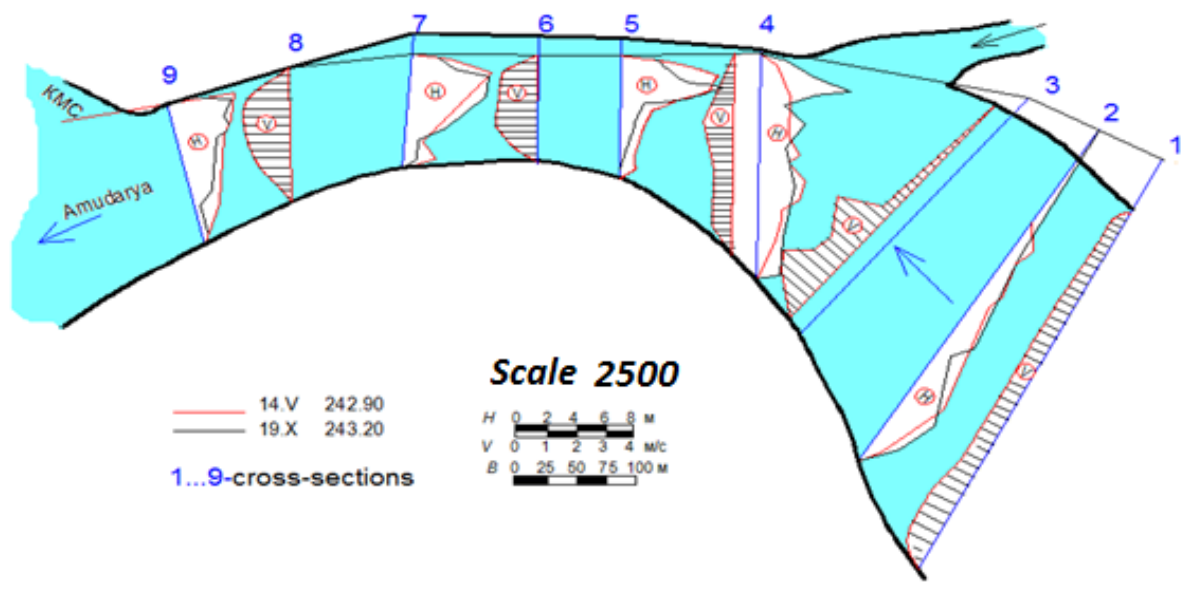

Fig. 1. Plan of the Amudarya river canal in the area of the KMC water intake and plots of depth $(H)$ and surface velocity $(v)$ of water.

The optimal route and boundaries of the location of the pioneer ditch are assigned depending on the location of the main stream of the river relative to the point of the damless water intake. When the main flow moves away from this point to the opposite bank of the river, the volume of the adjustment work bed increases, while approaching it decreases. Its temporary organization of production, the canal of adjustment work on the separation of the pioneer dug and its systematic cleaning makes it possible to ensure guaranteed water intake during the period of low water levels in the river with intensive wandering of the flow $[27,28]$.

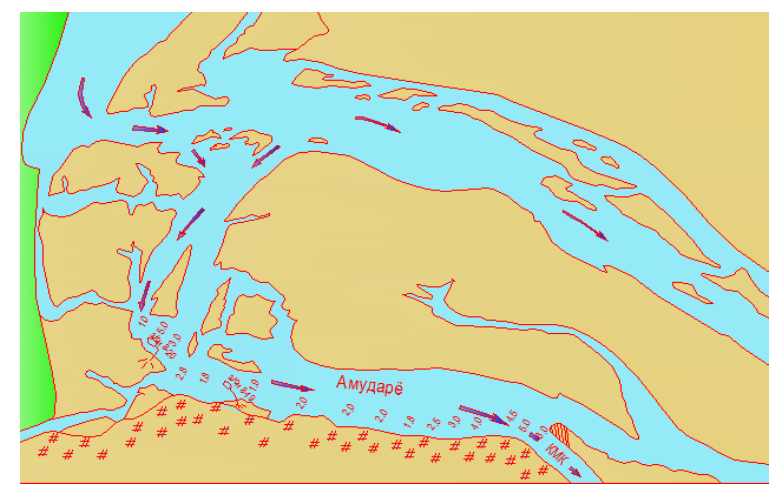

a) $\quad 10.03 .2018$

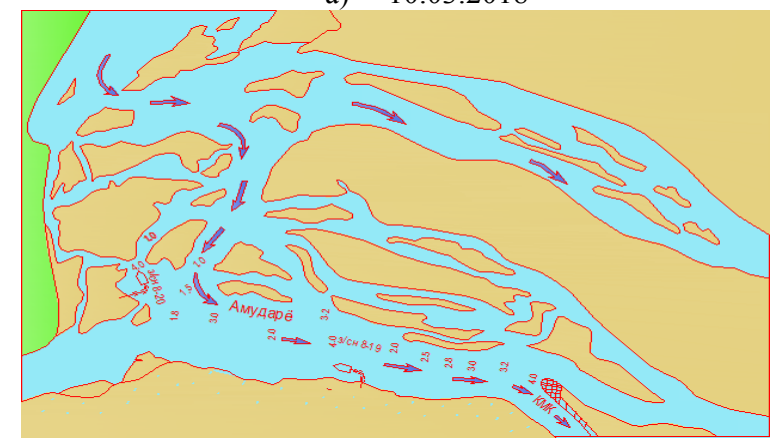

b)

04.03.2019

Fig. 2. Situational diagram of the KMC damless water intake 
According to the recommended method, the ditch route should be planned based on the location of its head on a straight-line section of the river with an outlet angle of no more than 300. The development of the hole must be carried out during the low-water period (September - April), that is, during the period of the least dependence of the canal by traction $[10,16,29]$. The length, width and depth of the pioneer ditch should be assigned depending on the planned location of the river canals relative to the point of the damless water intake, the alluvial regime of the river and the technical parameters of the dredgers (Fig. 2).

The length of the pioneer dug should be determined based on the planned location of the ducts relative to the water intake point. The depth of excavation of the hole is established from the conditions of silting (Fig. 3).

To determine the effective amount of sediment, when, in accordance with their hydraulic size, they settle to the bottom for a length $l$, the following formula is recommended:

$$
q_{l}=q_{n} \frac{l \bar{u}}{h \vartheta}
$$

where: $q_{n}$ - total suspended load, $k g ; \vartheta$ - average water flow rate, $m / s ; l$ - slot length, $m ; \overline{\mathrm{u}}$ - hydraulic particle size, $\mathrm{m} / \mathrm{c} ; h$ - water depth before excavation.

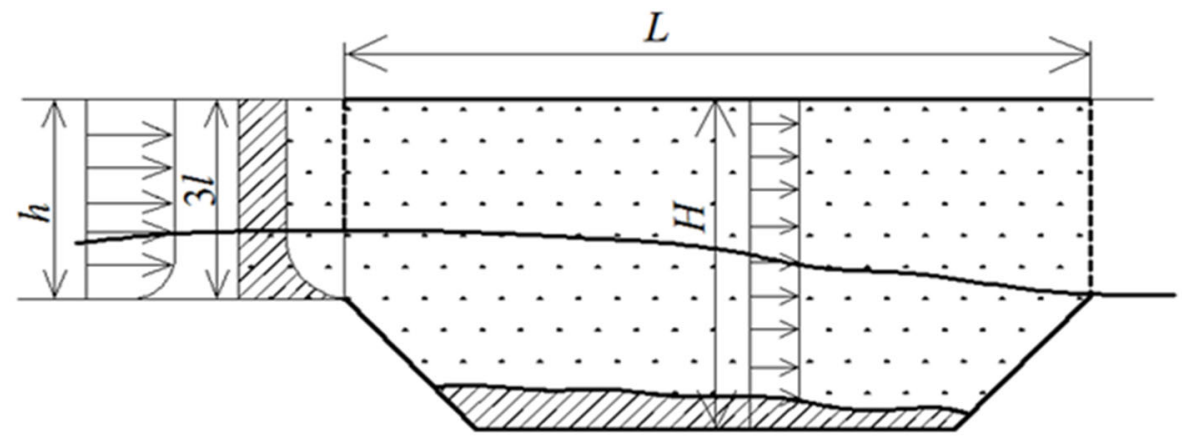

Fig. 3. Digging depth diagram for silting conditions.

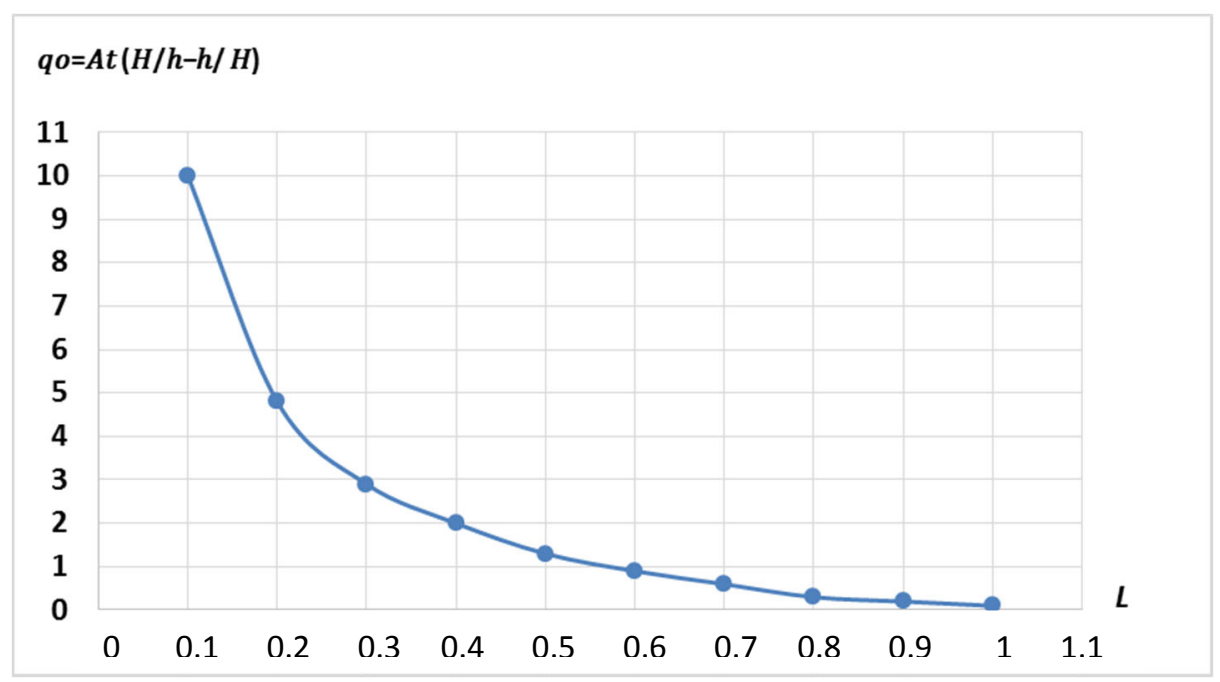

Fig. 4. Design scheme to explain the physical meaning of the concept of «effective amount of sediment». 
The total amount of sediment is determined by the formula:

$$
q_{n}=B \cdot H \cdot \vartheta \cdot \rho \cdot t
$$

where: $B$ - slot width, $\mathrm{m} ; \rho$ - average sediment concentration, $\mathrm{kg} / \mathrm{m}^{3} ; t$ - time, sec; $H-$ water depth after development, $\mathrm{m}$.

The amount of sediment deposited in the cut can be determined by the formula:

$$
q_{o}=k q_{c}\left(1-\frac{\vartheta_{\mathrm{p}}^{2}}{\vartheta_{\mathrm{g}}^{2}}\right)
$$

where: $k$ - coefficient taking into account the part of the effective amount of sediment involved in siltation: $\vartheta_{g}, \vartheta_{p}-$ flow rates in the bottom hole and in the canal, $\mathrm{m} / \mathrm{s}$. From the equation of continuity of flows:

$$
\vartheta_{p} \cdot h=\vartheta_{g} \cdot H
$$

We have

$$
\frac{\vartheta_{g}}{\vartheta_{p}}=\frac{h}{H}
$$

Hence, substituting (1) into (3), taking into account (5), we obtain

$$
q_{o}=k q \frac{l \bar{u}}{h \vartheta} \cdot \frac{H^{2}-h^{2}}{H^{2}}
$$

Taking into account (2), equation (6) is reduced to the form

$$
q_{o}=k q \bar{u} B l t\left(\frac{H}{h}-\frac{h}{H}\right)
$$

By designating $k q \bar{u} B l t=A_{t}$, receive,

$$
q_{o}=A_{t}\left(\frac{H}{h}-\frac{h}{H}\right)
$$

With the same value $A_{t}$ value $f\left(\frac{H}{h}-\frac{h}{H}\right)$ is defined by hyperbole (Fig. 4). The value of $k$ in equation (6) was obtained by Indian researchers during work on deepening the bottom of canals in the India river ports and was equal to 0.29 . Formula (8) can be used when choosing the depth $(H)$ of development, especially in places where there is a normal supply of sand fractions.

Establishing the development depth from the condition of a given throughput determines the width of the hole and the average flow rate

$$
\begin{gathered}
B=\frac{Q}{H \vartheta}=\frac{n Q}{H^{\frac{5}{3}} \sqrt{i}} \\
\vartheta=\frac{H^{\frac{2}{3}} \sqrt{i}}{n}
\end{gathered}
$$

where $Q$ - water discharge in the pit; $n$ - canal roughness coefficient; $i$ - the slope of the bottom or water surface of the water in the trench. 


\section{Conclusions}

Based on the discussion of the results of monitoring the dynamics of the river bed morphometry and the hydraulic parameters of the water flow of the damless water intake of the $\mathrm{KMC}$, the following conclusions can be drawn:

1. At present, on the Amudarya, in the areas of the damless water intake, the canal is regulated by the canal operation services, when the pioneer ditch route is planned intuitively, and the dredgers are placed to clean it without taking into account the traffic regime and the intensity of the canal process in the river.

2. In the recommended method, the rational use and placement of a fleet of dredgers during the laying the ditch route and its cleaning are achieved by taking into account the intensity of the canal process course in the river and the introduction of the ditch by entrained sediments. Thus, studies have established that in the river bed, coastal deformations occur more intensely than deep ones.

3. The water discharge in the area of the damless water intake during the year varies in a wide range and has a sharply variable character.

4. The relationship between the morphometric parameters of the canal and the hydraulic parameters of the flow in the area of the damless water intake at the KMC is unstable.

5. The depth of the flow changes intensively in a wide redistribution.

6. To prevent negative phenomena, it becomes necessary to conduct experimental and numerical studies aimed at regulating the direction of the flow and the nature of planned deformation in the area of the damless water intake.

\section{References}

1. A. Krutov, B. Norkulov, F. Uljaev, F. Jamalov, Results of a numerical study of currents in the vicinity of a damless water intake, IOP Conference Series: Materials Science and Engineering, 1030 (2021) DOI: 10.1088/1757-899x/1030/1/012121

2. D. Bazarov, I. Markova, B. Norkulov, O. Vokhidov, Hydraulic aspects of the layout of head structures during water intake from lowland rivers, IOP Conference Science, Materials, 1015 (2021) DOI: 10.1088/1757-899X/1015/1/012041

3. B. Dilshod, I. Markova, S. Sultanov, F. Kattakulov, Dynamics of the hydraulic and alluvial regime of the lower reaches of the Amudarya after the commissioning of the Takhiatash and Tuyamuyun hydrosystems, IOP Conference Series: Materials Science and Engineering, 1030 (2021) DOI: 10.1088/1757-899X/1030/1/012110.

4. D. Bazarov, N. Vatin, O. Bakhtiyor, V. Oybek, Hydrodynamic effects of the flow on the slab of the stand in the presence of cavitation, IOP Conference Series: Materials Science and Engineering. 1030 (2021) DOI: 10.1088/1757-899X/1030/1/012116

5. S. Eshev, S. Latipov, A. Qurbonov, J. Sagdiyev, M. Berdiev, V. Mamatov, Noneroding speed of water flow of canal s running in cohesive soils, IOP Conference Series: Materials Science and Engineering. 1030 (2021) DOI: 10.1088/1757899x/1030/1/012131

6. S. Eshev, A. Rakhimov, I. Gayimnazarov, A. Isakov, B. Shodiev, F. Bobomurodov, Dynamically stable sections of large soil canals taking into account wind waves, IOP Conference Series: Materials Science and Engineering, 1030, 012134 (2021) DOI: 10.1088/1757-899x/1030/1/012134.

7. S. Khidirov, G. Jumaboeva, Z. Ishankulov, Hydraulic mode of operation of the Takhiatash hydroelectric complex, IOP Conference Series: Materials Science and Engineering, 1030, 012120 (2021) DOI: 10.1088/1757-899X/1030/1/012120

8. E. Kan, A. Muratov, M. Yusupov, N. Ikramov, Calculation of water hammer on the 
pressure pipeline of modernized irrigation pumping station, IOP Conference Series: Materials Science and Engineering, 1030, 01217 (2021) DOI: 10.1088/1757899x/1030/1/012127

9. B. Urishev, F. Artikbekova, D. Kuvvatov, F. Nosirov, U. Kuvatov, Trajectory of sediment deposition at the bottom of water intake structures of pumping stations, IOP Conference Series: Materials Science and Engineering, 1030, 012137 (2021) DOI: 10.1088/1757-899x/1030/1/012137

10. B. Uralov, R. Choriev, L. Maksudova, Substantiation of the influence of the canal shape and the roughness of machine canals on the pressure loss of irrigation pumping stations, IOP Conference Series: Materials Science and Engineering, 1030, 012148 (2021) DOI: 10.1088/1757-899X/1030/1/012148

11. D. Bazarov, I. Markova, B. Norkulov, K. Isabaev, M. Sapaeva, Operational efficiency of water damless intake, IOP Conference Series: Materials Science and Engineering, 869(7) 072051, (2020) DOI: 10.1088/1757-899X/869/7/072051

12. D. Bazarov, B. Uralov, B. Matyakubov, O. Vokhidov, F. Uljaev, M. Akhmadi, The effects of morphometric elements of the canal on hydraulic resistance of machine canal $s$ of pumping stations, IOP Conference Series: Materials Science and Engineering, 869(7), 072015 (2020) DOI: 10.1088/1757-899X/869/7/072015.

13. R. Ergashev,N. Ismoilov, N. Nasirova, B. Kholbutaev, K. Khusanbayeva, O. Nazarov, Technology of water supply to water inlets of pumping stations, IOP Conference Series: Materials Science and Engineering 1030, 012156 (2021) DOI: 10.1088/1757899x/1030/1/012156

14. O. Glovatsky, R. Ergashev, N. Nasirova, B. Kholbutaev, k. Khusanbayeva, Estimation of the forecast of pump ready rate for reclamation systems, IOP Conference Series: Materials Science and Engineering, 1030, 012115 (2021) DOI: 10.1088/1757$899 x / 1030 / 1 / 012115$

15. O. Glovatsky, B. Hamdamov, F. Bekchanov, A. Saparov, Strengthening technology and modeling of dams from reinforced soil, IOP Conference Series: Materials Science and Engineering, 1030, 012155 (2021) DOI: 10.1088/1757-899x/1030/1/012155

16. B. Matyakubov, I. Begmatov, I. Raimova, G. Teplova, Factors for the efficient use of water distribution facilities, IOP Conference Series: Materials Science and Engineering, 883, 012025 (2020) DOI: 10.1088/1757-899x/883/1/012025

17. B. Uralov, N. Rakhmatov, S. Khidiro, G. Safarov, Hydraulic modes of damless water intake, IOP Conference Series: Materials Science and Engineering, 1030, 012123 (2021) DOI: 10.1088/1757-899X/1030/1/012123

18. D. Bazarov, O. Vokhidov, Extinguishing Excess Flow Energy in Spillway Structures, In book: Proceedings of, EECE 2020, 150, 535-545 (2021) DOI: 10.1007/978-3-03072404-7 52

19. A. P. Gurev, D. V. Kozlov, N. V. Khanov, M. M. Abidov, N. A. Safonova, Alternative Solutions for the Energy Dissipation of Idle Discharges at the Rogun HPP, Power Technology and Engineering, 54(1), 7-12 (2020)

20. E. V. Baranov, A. P. Guryev, N. V. Khanov, Recommendations for Hydraulic Calculations of Anti-Erosion Lining with the Use of Spatial Geogrid with Coarse Fragmental Soil, Power Technology and Engineering, 53(5), 553-556 (2020)

21. N. V. Khanov, D. Y. Martynov, A. I. Novichenko, N. V. Lagutina, S. M. Rodionova. Outlook and Special Properties of Earth Anchors and Screw Piles in Burial of Modular Protection Dikes in Nonrocky Ground, Power Technology and Engineering, 52(4), 405-412 (2018)

22. S. E. Bednaruk, V. V. Chukanov, E. M. Klenov, D. V. Kozlov, Accounting for the Thermal State of the Sayano-Shushenskaya Dam to Determine the Safe Maximum Water Levels in the Reservoir in Developing Its Dispatch Schedules, Power 
Technology and Engineering, 54(4), 451-455 (2020)

23. D. Kozlov, A. Yurchenko, The role of inspection of hydraulic structures in the assessment of their technical condition, IOP Conference Series: Materials Science and Engineering, 883(1) 012049 (2020)

24. R. Kh. Mukhametrakhimov, I. R. Aliullova, Improvement of the quality control system for expansion joints with rubber compensators during the repair of bridge constructions, Izvestiya KGASU, 3(53), 47-55 (2020)

25. R. Kh. Mukhametrakhimov, A. A Panchenko, Features of the quality control system for the construction of outdoor water supply and sewerage networks, Izvestiya KGASU. 4(42), 360-367 (2017)

26. D. V. Kozlov, S. L. Kuleshov, Multidimensional Data Analysis in the Assessment of Ice-Jam Formation in River Basins, Water Resources, 46(2), 152-159 (2019)

27. D. Bazarov, F. Shaazizov, S. Erjigitov, Transfer of Amudarya flowing part to increase the supportability of the Uzbekistan southern regions, IOP Conference Series: Materials Science and Engineering, 883, 012068 (2020) DOI: 10.1088/1757899x/883/1/012068

28. D. Bazarov, I. Markova, I. Raimova, S. Sultanov, Water flow motion in the vehicle of main canals, IOP Conference Series: Materials Science and Engineering, 883, 012001 (2020) DOI: $10.1088 / 1757-899 x / 883 / 1 / 012001$.

29. F. Atykbekov, F. Uljaev, G. Jumaboeva, A. Gayur, Z. Ishankulov, O. Jumanov, Operation damless intake of the Amudarya river (Central Asia), IOP Conference Series: Materials Science and Engineering, 883, 012003 (2020) DOI: 10.1088/1757899X/883/1/012003 